\title{
A Bioelectrocatalysis Method for the Kinetic Measurement of Thermal Inactivation of a Redox Enzyme, Bilirubin Oxidase
}

\author{
Tokuji IKeda, ${ }^{* \dagger}$ Hirosuke Tatsumi,* Hajime Katano,* Mizue WanibuchI,* Takao HibI,* \\ and Tsutomu KaJINO**
}

*Department of Bioscience, Fukui Prefectural University, Fukui 910-1195, Japan

**Toyota Central R \& D Labs Inc., Yokomichi, Nagakute, Aichi 480-1192, Japan

\begin{abstract}
The thermal stability of a redox enzyme, bilirubin oxidase (BOD), has been quantitatively evaluated by measuring the inactivation kinetics of $\mathrm{BOD}$ at several temperatures. The enzyme activity is directly related to the mediated bioelectrocatalytic current for the BOD-catalyzed reduction of $\mathrm{O}_{2}$. Thus, the inactivation process is measured by the timedependent decrease in the bioelectrocatalytic current. The results reveal that the inactivation obeys first-order kinetics, whose rate constants $(k)$ are determined at $\mathrm{pH} 7.0$ and at $50-70^{\circ} \mathrm{C}$. The half life of BOD activity, calculated from the $k$ value at $50^{\circ} \mathrm{C}$ is $114 \mathrm{~min}$, which is in harmony with the thermal-stability data given in a catalog by Amano Enzyme Inc. The bioelectrocatalysis method allows in situ measurements of the inactivation kinetics in the period of a few minutes at relatively high temperatures. The rate constants show a large temperature dependence, leading to a large Arrhenius activation energy $\left(E_{\mathrm{A}}\right)$ of $221 \mathrm{~kJ} \mathrm{~mol}^{-1}$. The activation Gibbs energy $\left(\Delta G^{\ddagger}\right)$, activation enthalpy $\left(\Delta H^{\ddagger}\right)$, and activation entropy $\left(\Delta S^{\neq}\right)$are also determined.
\end{abstract}

(Received October 1, 2007; Accepted December 10, 2007; Published February 10, 2008)

\section{Introduction}

Enzymes have found a variety of industrial applications. They have been used, for example, in fiber processing, environmental purification, ${ }^{1}$ and clinical analysis, ${ }^{1-3}$ and as ingredients of detergents, ${ }^{1}$ and electrocatalysts of biofuel cells. ${ }^{3-5}$ In such industrial applications, enzymes are required to be stable for an appropriate period of time, and the technology of stability improvement has been intensively developed by the method of trial and error. Recently, protein engineering based on structural biology has also been introduced for an improvement. ${ }^{6}$ In combination with structural information, kinetic studies providing macroscopic information on the inactivation mechanism are helpful for designing stable enzymes. The kinetic study is also useful for quantitative evaluations of the thermal stability of enzymes, which is in many cases expressed as the residual activity of an enzyme after a treatment for a given period of time, say, $30 \mathrm{~min}$ at a given temperature of, say, $60^{\circ} \mathrm{C} .^{7}$

Mostly, enzyme activity is measured by a spectrophotometric method, in which the rate of the enzymatic reaction is measured by recording the absorbance-time curve reflecting the timedependent increase (decrease) of the product (substrate). The slope of the curve is proportional to the enzyme activity. When inactivation proceeds during the measurement, the curve will bend downward. It is a tedious and difficult task to extract the inactivation effect from the curve. In the bioelectrocatalysis

† To whom correspondence should be addressed.

M. W. present address: Division of Applied Life Sciences, Graduate School of Agriculture, Kyoto University, Sakyo, Kyoto 606-8502, Japan. method, ${ }^{8}$ on the contrary, enzyme activity is measured as a steady state bioelectrocatalytic current, which is time independent. A time dependent decrease, if occurs, it is attributed to inactivation of the enzyme accordingly, and the data of the time-dependent current decrease are directly utilized for a kinetic analysis of the inactivation.

In this work, we attempted to apply the bioelectrocatalysis method for measurements of the inactivation kinetics of a redox enzyme. We have taken bilirubin oxidase (BOD) as the redox enzyme, which has been proved to be a promising enzyme as a cathode catalyst in biofuel cells..$^{3-5,9-11}$ BOD is a multicopper (one Type 1, one Type 2, and one set of Type 3 coppers) $)^{12}$ oxidase catalyzing the oxidation of bilirubin to biliverudin and other substrates. We have shown ${ }^{13}$ that $\mathrm{Fe}(\mathrm{CN})_{6}{ }^{4-}$ functions as an excellent electron donor of BOD and as an electron-transfer mediator to produce a large catalytic current for the reduction of $\mathrm{O}_{2}$ to water. Here, we tried to apply the $\mathrm{Fe}(\mathrm{CN})_{6}{ }^{4-}$ mediated bioelectrocatalytic current for in situ measurements of the inactivation process of BOD at relatively high temperatures.

\section{Experimental}

Reagents and chemicals

Bilirubin oxidase (BOD; EC 1.3.3.5) from Myrothecium verrucaria was donated by Amano Enzyme Inc. $(2.83 \mathrm{U} / \mathrm{mg}$, Lot No. BOBO551301), which was stored at $-80^{\circ} \mathrm{C}$. One milliliter of a BOD solution was prepared with $50 \mathrm{mM}$ phosphate buffer $(\mathrm{pH} 7.0)$, and the BOD concentration was determined spectrophotometrically using $\varepsilon_{600}=4800 \mathrm{M}^{-1} \mathrm{~cm}^{-1} \cdot{ }^{14}$ The BOD solution was divided into 10 portions of $0.1 \mathrm{~mL}$ volume each and stored at $-80^{\circ} \mathrm{C}$ until use. A $0.1-\mathrm{mL}$ portion of the BOD solution was brought to $0^{\circ} \mathrm{C}$ in ice and used up in a 
series of experiments in the same day. Stock solutions of 10 $\mathrm{mM} \mathrm{Fe}(\mathrm{CN})_{6}{ }^{3-}$ and $0.1 \mathrm{M} \mathrm{Fe}(\mathrm{CN})_{6}{ }^{4-}$ were freshly prepared every two weeks from $\mathrm{K}_{3}\left[\mathrm{Fe}(\mathrm{CN})_{6}\right]$ and $\mathrm{K}_{4}\left[\mathrm{Fe}(\mathrm{CN})_{6}\right] 3 \mathrm{H}_{2} \mathrm{O}$, respectively. All chemicals used were of analytical reagent grade, and all solutions were prepared with distilled water.

\section{Apparatus and procedure}

Electrochemical measurements were carried out with a homemade electrochemical analyzer. A glassy carbon electrode $(\phi=$ $3 \mathrm{~mm}$; BAS Co.), a platinum coil, and an $\mathrm{Ag} \mid \mathrm{AgCl}(0.1 \mathrm{M} \mathrm{KCl})$ electrode were used as the working electrode, counter electrode, and reference electrode, respectively. The potential is referred to as the $\mathrm{Ag} \mid \mathrm{AgCl}(0.1 \mathrm{M} \mathrm{KCl})$ electrode in the following. A home-made electrolysis cell of $10 \mathrm{~mL}$ volume with a water jacket was used, whose temperature was controlled by circulating water kept at a constant temperature with a water bath (Thermominder 50; Taitec Co.). The temperature of a test solution $(5 \mathrm{~mL})$ in the electrolysis cell was monitored with a digital thermometer (SK-250WP II-N, 15849; Sato Keiryouki Co.). All electrochemical measurements were performed in airsaturated solutions. Spectrophotometric measurements were performed with a JASCO V-530 UV VIS spectrophotometer at room temperature.

\section{Results and Discussion}

BOD catalyzes the following reaction very effectively:

$$
4 \mathrm{Fe}(\mathrm{CN})_{6}{ }^{4-}+4 \mathrm{H}^{+}+\mathrm{O}_{2} \longrightarrow 4 \mathrm{Fe}(\mathrm{CN})_{6}^{3-}+2 \mathrm{H}_{2} \mathrm{O}
$$

The rate of the catalytic reaction $(v)$ is written by the MichaelisMenten type equation,

$$
v=\frac{k_{\mathrm{cat}}[\mathrm{BOD}]}{1+\left(K_{\mathrm{s}} /\left[\mathrm{O}_{2}\right]\right)+\left(K_{\mathrm{M}} /\left[\mathrm{Fe}(\mathrm{CN})_{6}{ }^{4-}\right]\right)},
$$

where $k_{\text {cat }}$ is the catalytic constant, [BOD] is the concentration of BOD, $K_{\mathrm{s}}$ and $K_{\mathrm{M}}$ are the Michaelis constant for $\mathrm{O}_{2}$ and $\mathrm{Fe}(\mathrm{CN})_{6}{ }^{4-}$, respectively. Reaction (1) can be coupled with the electrode reaction,

$$
\mathrm{Fe}(\mathrm{CN})_{6}^{3-}+\mathrm{e}^{-} \longrightarrow \mathrm{Fe}(\mathrm{CN})_{6}^{4-},
$$

to produce a mediated bioelectrocatalytic current for the reduction of $\mathrm{O}_{2}{ }^{15}$

The catalytic current is given by Eq. (4) in a steady state in a limiting current region under the condition $K_{\mathrm{s}} /\left[\mathrm{O}_{2}\right] \ll 1,{ }^{16}$ which is fulfilled in an air-saturated solution.

$$
I_{1, \text { bcat }}=n_{\mathrm{M}} F A \sqrt{\left(n_{\mathrm{s}} / n_{\mathrm{M}}\right) D_{\mathrm{M}} k_{\mathrm{cat}} K_{\mathrm{M}}[\mathrm{BOD}]} \sqrt{2\left[\frac{[\mathrm{M}]^{*}}{K_{\mathrm{M}}}-\ln \left(1+\frac{[\mathrm{M}]^{*}}{K_{\mathrm{M}}}\right)\right]}
$$

$$
=f\left([\mathrm{M}]^{*}\right)[\mathrm{BOD}]^{1 / 2},
$$

where $I_{1, \text { bcat }}$ denotes the limiting catalytic current in a steady state; $n_{\mathrm{s}}$ and $n_{\mathrm{M}}$ are the number of electrons involved in Eqs. (1) and (3), respectively; $F$ and $A$ are the Faraday constant and the electrode surface area; $D_{\mathrm{M}}$ and $[\mathrm{M}]^{*}$ are the diffusion coefficient and the concentration of $\mathrm{Fe}(\mathrm{CN})_{6}{ }^{3-}$, respectively.

Equation (4) (Eq. (4')) shows that $I_{1, \text { bcat }}$ is proportional to $[\mathrm{BOD}]^{1 / 2}$. To confirm this, we measured cyclic voltammograms $(\mathrm{CVs})$ of $\mathrm{Fe}(\mathrm{CN})_{6}{ }^{3-}$ in an air-saturated solution containing BOD at several concentrations at $30^{\circ} \mathrm{C}$. The results shown in Fig. 1A
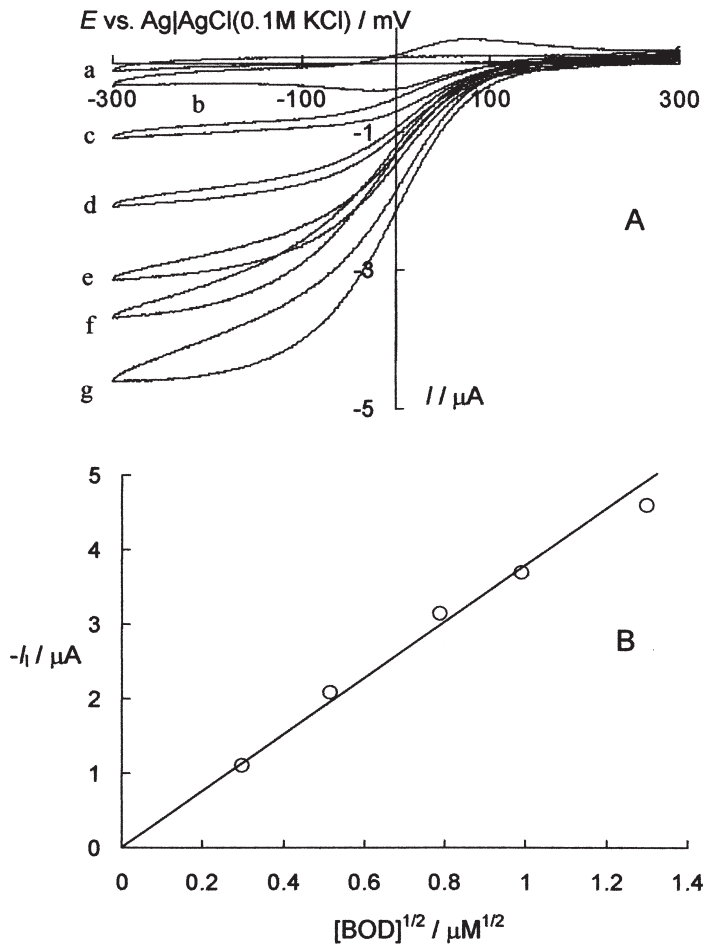

Fig. 1 A: Cyclic voltammograms of: a, air saturated $50 \mathrm{mM}$ phosphate buffer (pH 7.0); b, $50 \mu \mathrm{M} \mathrm{Fe}(\mathrm{CN})_{6}{ }^{3-}$ in a; c - g, $89 \mathrm{nM}$, $0.27 \mu \mathrm{M}, 0.62 \mu \mathrm{M}, 0.98 \mu \mathrm{M}$, and $1.69 \mu \mathrm{M}$ BOD in $\mathrm{b}, 30^{\circ} \mathrm{C}$; scan rate, $5 \mathrm{mV} \mathrm{s}^{-1}$. B: Dependence of $-I_{1}$ at $-0.3 \mathrm{~V}$ on $[\mathrm{BOD}]^{1 / 2}$.

demonstrate that the CVs in the presence of BOD (c - g in Fig. 1A) exhibit an S-shaped pattern with steady state limiting currents, which are typical of mediated bioelectrocatalytic reactions. A plot of the limiting current $\left(-I_{1}\right)$ against $[\mathrm{BOD}]^{1 / 2}$ (Fig. 1B) shows that $-I_{1}$ is proportional to [BOD $]^{1 / 2}$ in satisfying Eq. (4), at least up to $1 \mu \mathrm{M}$ of BOD. It should be noted that since the cathodic current is defined to have a minus sign, the positive quantity $-I_{1}$ is used in the analysis.

We have next recorded CVs at a higher temperature $50^{\circ} \mathrm{C}$ in a phosphate buffer solution containing $0.1 \mathrm{mM} \mathrm{Fe}(\mathrm{CN})_{6}{ }^{3-}$ and $0.36 \mu \mathrm{M}$ BOD. When the CVs were recorded several times at appropriate intervals for a few hours, the limiting current $\left(I_{1}\right)$ gradually decreased as illustrated in Fig. 2A. The timedependent decrease in $I_{1}$ may be attributed to a decrease in the BOD concentration (Eq. (4)) to form an inactive form, or a decrease in the catalytic constant, $k_{\text {cat }}$, of BOD (Eqs. (2) and (4)) due to a conformational change of the BOD. When we plot $\ln \left(-I_{1}\right)$ against time $(t)$, it gives a straight line (B in Fig. 2), suggesting a first-order kinetics of the inactivation. Thus, we assume the following simple mechanism of inactivation:

$$
\mathrm{BOD} \longrightarrow \mathrm{iBOD}
$$

where iBOD denotes an inactive form of BOD. The rate of inactivation $\left(v_{\mathrm{i}}\right)$ is written as

$$
v_{\mathrm{i}}=-\frac{\mathrm{d}[\mathrm{BOD}]}{\mathrm{d} t}=k[\mathrm{BOD}]
$$

and

$$
\ln [\mathrm{BOD}]=-k t+\ln [\mathrm{BOD}]_{t=0},
$$

where $k$ is defined as the inactivation rate constant. Taking 



Fig. 2 A: Dependence of $-I_{1}(-0.3 \mathrm{~V})$ on the incubation time $t$ at $50^{\circ} \mathrm{C}$. B: Plot of $\ln \left(-I_{1}\right)$ against $t$.

Eq. (4) into accout, we can write

$$
\ln \left(-I_{1}\right)=-(1 / 2) k t+\ln \left(-I_{1}\right)_{t=0} .
$$

The $k$ value in Eq. (8) is determined to be $1.12 \times 10^{-4} \mathrm{~s}^{-1}$ from the slope of the plot in Fig. 2B.

We have also measured the inactivation kinetics by the conventional method of spectrophotometry. To start the inactivation process, $4 \mu \mathrm{L}$ of BOD solution $(86.3 \mu \mathrm{M})$ was injected into $1 \mathrm{~mL}$ of a phosphate buffer $(50 \mathrm{mM}, \mathrm{pH} 7.0)$ solution kept at $50^{\circ} \mathrm{C}$ in a water bath. Immediately after injection, the solution was gently stirred; then, $25 \mu \mathrm{L}$ of the solution was taken and injected into a phosphate buffer containing $2 \mathrm{mM} \mathrm{Fe}(\mathrm{CN})_{6}{ }^{4-}(2.8 \mathrm{nM}$ in BOD concentration) for the absorbance measurement at room temperature. The absorbance at $420 \mathrm{~nm}$ increased linearly for the first $100 \mathrm{~s}$ due to the production of $\mathrm{Fe}(\mathrm{CN})_{6}{ }^{3-}$. The slope gives the initial rate of the BOD catalyzed reaction (Eq. (2)), which reflects the BOD activity. In the same way, $25 \mu \mathrm{L}$ portions of the BOD solution in the water bath were taken at appropriate intervals during incubation; then, the enzyme activities were measured. The activity is expressed as $\Delta$ (absorbance) $/ 25 \mathrm{~s}$ and plotted against the incubation time $t$ in Fig. 3A. When plotted as $\ln [\Delta$ (absorbance) $/ 25 \mathrm{~s}]$ vs. $t$ (Fig. $3 \mathrm{~B}$ ), it gives a straight line, from which the $k$ value is determined by Eq. (7) to be $9.17 \times$ $10^{-5} \mathrm{~s}^{-1}$. This agrees well with that obtained as mentioned above by the electrochemical method. The half life $(\tau)$ of the BOD activity is calculated from the $k$ values as $\tau=114 \mathrm{~min}$ at $50^{\circ} \mathrm{C}$, and the residual activity after $30 \mathrm{~min}$ is $83.3 \%$ of the original activity. These are in harmony with the thermal-stability data given in the Catalog of Amano Enzyme Inc., ${ }^{7}$ where the data are given as the residual activities after a treatment for $30 \mathrm{~min}$ at several temperatures.

An advantage of the electrochemical method is that it allows an in situ measurement at a given temperature. Figure 4 shows a current time curve recorded at $-0.3 \mathrm{~V}$ and at $30^{\circ} \mathrm{C}$ of the $\mathrm{pH}$ 7.0 phosphate buffer $(50 \mathrm{mM})$ containing $50 \mu \mathrm{M} \mathrm{Fe}(\mathrm{CN})_{6}{ }^{3-}$ and $0.36 \mu \mathrm{M}$ BOD. When the circuit was closed, the current for the mediated bioelectrocatalytic reaction appeared, and attained a

steady state within $1 \mathrm{~min}$. The steady state currrent was kept practically constant for, at least for $25 \mathrm{~min}$, indicating that the BOD activity remained unchanged during the measurment. In contrast, when we measured the current time curve at $70^{\circ} \mathrm{C}$, the current decreased rapidly with time, as illustrated in Fig. 5. The current was first measured at $-0.3 \mathrm{~V}$ in a $50 \mathrm{mM}$ phosphate buffer ( $\mathrm{pH} 7.0)$ containing $0.1 \mathrm{mM} \mathrm{Fe}(\mathrm{CN})_{6}{ }^{3-}$. When the solution was stirred with a magnetic stirring bar (arrow a), a spike appeared and returned after about $20 \mathrm{~s}$ to the original magnitude of the diffusion current of $\mathrm{Fe}(\mathrm{CN})_{6}{ }^{3-}$ in a quiet solution. BOD was then added at arrow $\mathrm{b}$ to make $0.35 \mu \mathrm{M}$ in BOD with gentle stirring of the solution. Immediately after BOD addition, a large current for the mediated bioelectrocatalytic reaction appeared, but the current decreased rapidly to the original current in the absence of BOD. The result indicates that the BOD activity disappears within several minutes.

It is noted that the diffusion current for the reduction of $\mathrm{Fe}(\mathrm{CN})_{6}{ }^{3-}$ seems to remain constant during the course of recording. This is because the edge effect at the GC electrode becomes significant at longer times of recording ${ }^{17}$ (e.g. 69\% at 


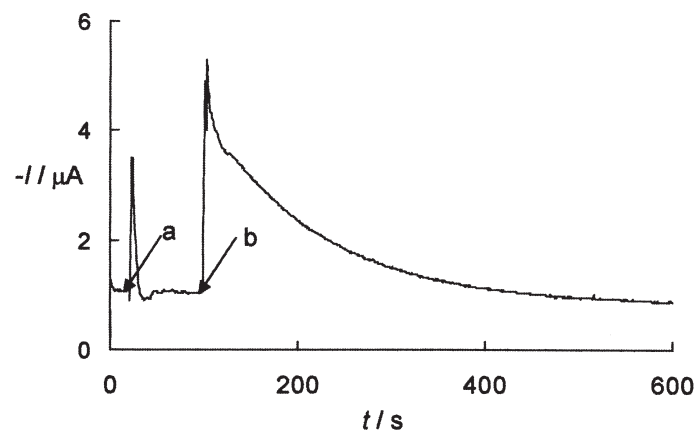

Fig. 5 Current $(-I$ at $-0.3 \mathrm{~V})$ vs. time $t$ curve of a $0.1 \mathrm{mM}$ $\mathrm{Fe}(\mathrm{CN})_{6}{ }^{3-}$ phosphate buffer $(\mathrm{pH} 7.0)$ solution kept at $70^{\circ} \mathrm{C}$. At the point indicated by arrow a, the solution was stirred with a magnetic stirring bar for a few seconds, and at arrow b, BOD was added with gentle stirring to make $\mathrm{BOD}=0.35 \mu \mathrm{M}$.
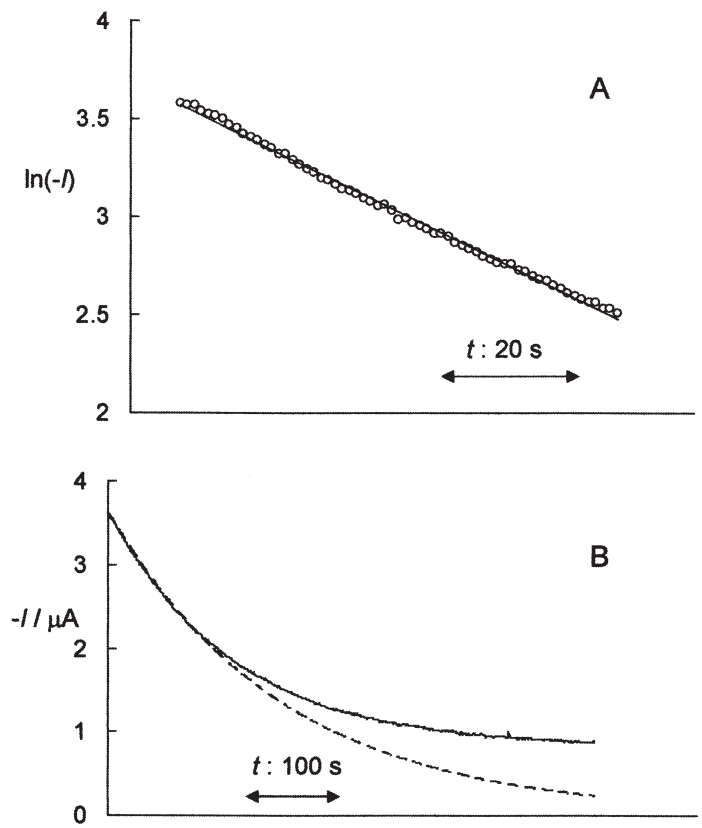

Fig. 6 A: Plot of $\ln \left(-I_{1}\right)$ against $t$ in the region from $t=175$ to $295 \mathrm{~s}$ of the curve in Fig. 5. B: Experimental $-I$ vs. $t$ curve (solid curve) and calculated one (broken curve); the calculation is detailed in the text.

300 s). Anyway, we must take into account the contribution of the diffusion current to the total current when the bioelectrocatalytic current is small. The theory of a simple catalytic current $\left(I_{1, \text { cat }}\right)$ for the reaction $\mathrm{O}+\mathrm{e}^{-} \rightarrow \mathrm{R}, \mathrm{R}+\mathrm{Z} \rightarrow \mathrm{O}$ $+\mathrm{Y}$ predicts that the equation for the current in a steady state is applicable only when $I_{1, \text { cat }} \gg 2.3 I_{\mathrm{d}}, I_{\mathrm{d}}$ is the diffusion current of $\mathrm{O}$ in the absence of Z. ${ }^{18}$ The same consideration is valid for $I_{1, \text { bcat }}$ in Eq. (4). ${ }^{19}$ Taking into account this effect and the stirring effect mentioned above, we took the data in Fig. 5 in the region corresponding a pure bioelectrocatalytic current (from $20 \mathrm{~s}$ after the BOD addition to $140 \mathrm{~s}$ ) to plot as $\ln \left(-I_{1}\right) v s$. $t$ in Fig. 6A. The plot gives a straight line, from which the $k$ value is determined as $1.19 \times 10^{-2} \mathrm{~s}^{-1}$. The broken curve in Fig. 6B illustrates the $-I_{1} v s$. $t$ curve by Eq. (8) using $k=1.19 \times 10^{-2} \mathrm{~s}^{-1}$ and the $-I_{1}$ data at $t=0(3.76 \mu \mathrm{A})$, which well reproduces the measured $-I_{1}$ vs. $t$ curve (solid curve) at $-I_{1}>2 \mu \mathrm{A}$. In conclusion, the electrochemical method based on mediated

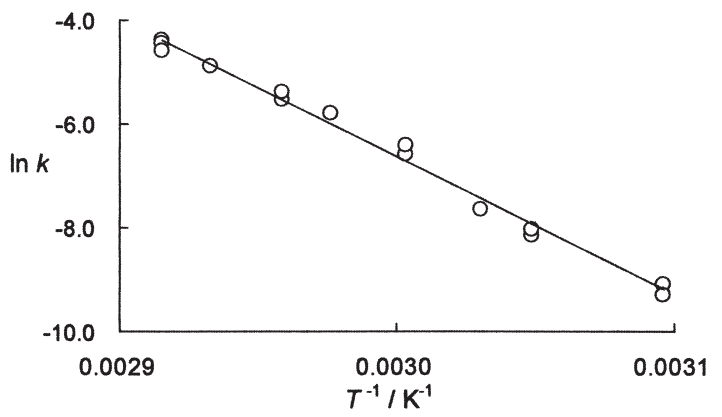

Fig. 7 Arrhenius plot of the rate constant $k$ for thermal inactivation of BOD.

bioelectrocatalysis allows in situ measurements of the inactivation kinetics of BOD within a few minutes. The $k$ value at $70^{\circ} \mathrm{C}\left(1.19 \times 10^{-2} \mathrm{~s}^{-1}\right)$ corresponds to a half life of $1 \mathrm{~min}$. It seems not to be easy to measure such fast inactivation kinetics by the conventional spectrophotometric method. ${ }^{20}$ The fact that the decay kinetics of $I_{1}$ depends on half of the rate constant $(k / 2)$ (Eq. (8)) favors measurements of faster inactivation kinetics.

The $k$ value at $70^{\circ} \mathrm{C}\left(1.19 \times 10^{-2} \mathrm{~s}^{-1}\right)$ is 100 -times larger than the $k$ value at $50^{\circ} \mathrm{C}\left(1.12 \times 10.4,0.917 \times 10^{-5} \mathrm{~s}^{-1}\right)$, suggesting a large activation energy. We measured $I_{1}-t$ curves by the method in Fig. 2 or Fig. 5 at various temperatures between 50 and $70^{\circ} \mathrm{C}$, and plotted the results as $\ln k v s .1 / T$ in Fig. 7 . Since the plot satisfies a linear relationship, we may assume the same reaction mechanism in the temperature range studied. The Arrhenius activation energy $\left(E_{\mathrm{A}}\right)$ was calculated to be $221 \mathrm{~kJ} \mathrm{~mol}^{-1}$ from the slope of the plot. The large activation energy indicates that BOD is stable at lower temperatures. For example, the half life at $60^{\circ} \mathrm{C}$ was calculated to be $7.5 \mathrm{~min}$, while the half life at $25^{\circ} \mathrm{C}$ is 39 days. We calculated the activation enthalpy $\left(\Delta H^{\neq}\right)$from the Arrhenius activation energy and activation Gibbs energy $\left(\Delta G^{\neq}\right)$from the $k$ values by $k=\left(k_{\mathrm{B}} T / h\right) \exp \left(-\Delta G^{\neq} / R T\right)$ and then the activation entropy $\left(\Delta S^{\neq}\right)$by $\Delta S^{\neq}=\left(\Delta H^{\neq}-\Delta G^{\neq}\right) / T$, where $k_{\mathrm{B}}$, $h$, and $R$ are the Boltzmann constant, the Plank constant and the gas constant, respectively. The results are summarized in Table 1. The activation Gibbs energy is less than half of the activation enthalpy, because of a large positive value of the activation entropy. A large Arrhenius activation energy and positive activation entropy are relatively common in the inactivation kinetics of oxidoreductases; for example, $E_{\mathrm{A}}=699 \mathrm{~kJ} \mathrm{~mol}^{-1}, \Delta S^{\neq}$ $=696 \mathrm{~J} \mathrm{~mol}^{-1} \mathrm{~K}^{-1}$ for methanol dehydrogenase, ${ }^{21} E_{\mathrm{A}}=330 \mathrm{~kJ}$ $\mathrm{mol}^{-1}, \Delta S^{\neq}=676 \mathrm{~J} \mathrm{~mol}^{-1} \mathrm{~K}^{-1}$ for glucose oxidase (Penicillium adametzil), ${ }^{22} E_{\mathrm{A}}=252 \mathrm{~kJ} \mathrm{~mol}^{-1}, \Delta S^{\neq}=434 \mathrm{~J} \mathrm{~mol}^{-1} \mathrm{~K}^{-1}$ for glucose oxidase (Aspergillus niger), ${ }^{23}$ and $E_{\mathrm{A}}=195$ and $145 \mathrm{~kJ}$ $\mathrm{mol}^{-1}, \Delta S^{\neq}=94$ and $237 \mathrm{~J} \mathrm{~mol}^{-1} \mathrm{~K}^{-1}$ for peroxidase isozymes (Eupatorium odoratum). ${ }^{24}$

BOD exists in solution as a monomer of molecular weight 59950 , composed of 534 amino acid residues containing one cysteine. ${ }^{25}$ The cysteine residue is supposed to play a role in the intramolecular electron transfer between a type 1 copper site and the trinuclear center composed of the type 2 and type 3 copper sites. ${ }^{26}$ Thus, the possibility of a monomer-dimer change, intra- and intermolecular disulfide bond formation (or cleavage) is precluded during the course of inactivation. The activation enthalpy would be a result of the cleavage of many numbers of weak non-covalent bonds within a BOD molecule, and the positive activation entropy would reflect an increasing local disorder in the inactivation process. Further studies are needed to understand the structural change behind the $\Delta H^{\ddagger}$ and $\Delta S^{\ddagger}$ values of BOD. Our studies are underway in such a direction. 
Table 1 Rate constant $(k)$ and kinetic parameters for thermal inactivation of BOD

\begin{tabular}{|c|c|c|c|c|}
\hline$T / \mathrm{K}$ & $\mathrm{k} / \mathrm{s}$ & $\Delta G^{\neq} / \mathrm{kJ} \mathrm{mol}^{-1}$ & $\Delta H^{\ddagger} / \mathrm{kJ} \mathrm{mol}^{-1}$ & $\Delta S^{\ddagger} / \mathrm{J} \mathrm{mol}^{-1} \mathrm{~K}^{-1}$ \\
\hline 323 & $(1.02 \pm 0.10) \times 10^{-4}(2)^{\mathrm{a}}$ & $104.1 \pm 0.2$ & 218.7 & $355 \pm 1$ \\
\hline 328 & $(3.08 \pm 0.20) \times 10^{-4}(2)^{\mathrm{a}}$ & $102.7 \pm 0.2$ & 218.7 & $354 \pm 1$ \\
\hline 330 & $4.80 \times 10^{-4}$ & 102.1 & 218.7 & 353 \\
\hline 333 & $(1.56 \pm 0.12) \times 10^{-3}(3)^{\mathrm{a}}$ & $99.8 \pm 0.2$ & 218.6 & $357 \pm 1$ \\
\hline 336 & $3.09 \times 10^{-3}$ & 98.8 & 218.6 & 357 \\
\hline 338 & $(4.20 \pm 0.27) \times 10^{-3}(3)^{\mathrm{a}}$ & $98.5 \pm 0.2$ & 218.6 & $355 \pm 1$ \\
\hline 341 & $7.58 \times 10^{-3}$ & 97.7 & 218.6 & 354 \\
\hline 343 & $(1.16 \pm 0.08) \times 10^{-2}(4)^{\mathrm{a}}$ & $97.1 \pm 0.2$ & 218.6 & $354 \pm 1$ \\
\hline
\end{tabular}

a. $(n)$ : number of run.

\section{Acknowledgements}

The author (T. I.) wishes to exppress his thanks to Amano Enzyme Inc., Nagoya, Japan for the kind gift of BOD.

\section{References}

1. “Kouso Kougaku (Enzyme Technology, in Japanese)", ed. S. Fukui, I. Chibata, and S. Suzuki, 1981, Tokyo-kagakudojin, Tokyo.

2. K. Kano and T. Ikeda, Bunseki (in Japanese), 2003, 576.

3. K. Kano and T. Ikeda, Electrochemistry, 2003, 71, 86.

4. "Baiodenkikagaku no Jissai-Baiosensa·Baiodenchi no Jitsuyou Tenkai (Practical Bioelectrochemistry-Recent Developments in Biosensors \& Biofuel Cells, in Japanese), ed. T. Ikeda, 2007, CMC Publishing, Tokyo.

5. S. C. Barton, J. Gallaway, and P. Atanasov, Chem. Rev., 2004, 104, 4867.

6. T. Hibi and Y. Nishiya, p.101 in Ref. 4.

7. Thermal stability of enzymes is expressed as such in catalogs of enzyme companies. For example, the thermal stability of BOD appears in Amano Enzyme Catalog, 18 (http://www.amano-enzyme.co.jp/jp/productinfo/medical 03.html).

8. T. Ikeda, Chem. Rec., 2004, 4, 192.

9. S. Tsujimura, H. Tatsumi, J. Ogawa, S. Shimizu, K. Kano, and T. Ikeda, J. Electroanal. Chem., 2001, 496, 69.

10. S. Tsujimura, M. Fujita, H. Tatsumi, K. Kano, and T. Ikeda, Phys. Chem. Chem. Phys., 2001, 3, 1331.

11. S. Tsujimura, K. Kano, and T. Ikeda, Electrochemistry, 2002, 70, 940 .

12. A. Shimizu, J. H. Kwon, T. Satoh, N. Sakurai, T. Sakurai,
S. Yamaguchi, and T. Samejima, Biochemistry, 1999, 38, 3034.

13. T. Nakagawa, S. Tsujimura, K. Kano, and T. Ikeda, Chem. Lett., 2003, 32, 54.

14. A. Shimizu, J. H. Kwon, T. Satoh, N. Sakurai, T. Sakurai, S. Yamaguchi, and T. Samejima, J. Biochem., 1999, 125, 662.

15. S. Tsujimura, M. Kawahara, T. Nakagawa, K. Kano, and T. Ikeda, Electrochem. Commun., 2003, 5, 138.

16. R. Matsumoto, K. Kano, and T. Ikeda, J. Electroanal. Chem., 2002, 535, 37.

17. T. Ikeda, H. Tatsumi, H. Katano, and K. Kano, p. 38 in Ref. 4.

18. A. J. Bard and L. R. Faulkner, "Electrochemical Methods: Fundamentals and Applications", 1980, John Wiley and Sons, New York, Chichester, Brisbane, Toronto, 457.

19. T. Ikeda, H. Tatsumi, H. Katano, and K. Kano, p. 43 in Ref. 4.

20. K. Hiromi, "Kouso Hannou Kaiseki no Jissai (Practice in Kinetic Analysis of Enzyme Reactions, in Japanese)", 1989, Koudansya, Tokyo, 54.

21. T. K. Harris and V. L. Davidson, Biochem. J., 1994, 303, 141.

22. A. N. Eremin, D. I. Metelitsa, Zh. F. Shishko, R. V. Mikhailova, M. I. Iasenko, and A. G. Lobanok, Prikl. Biokhim. Mikrobiol., 2001, 37, 678.

23. M. D. Gouda, S. A. Singh, A. G. Rao, M. S. Thakur, and N. G. Karanth, J. Biol. Chem., 2003, 278, 24324.

24. D. N. Rani and T. E. Abraham, Appl. Biochem. Biotechnol., 2006, 128, 215.

25. S. Koikeda, K. Ando, H. Kaji, T. Inoue, S. Murao, K. Takeuchi, and T. Samejima, J. Biol. Chem., 1993, 268, 18801.

26. A. Shimizu, J. H. Kwon, T. Sasaki, T. Satoh, N. Sakurai, T. Sakurai, S. Yamaguchi, and T. Samejima, Biochemistry, 1999, $38,3034$. 